\title{
Sarcoidosis Imitating Sjögren's Syndrome or the Association of Sarcoidosis - Sjögren's Syndrome
}

\author{
Sjögren Sendromunu Taklit Eden Sarkoidoz veya Sarkoidoz-Sjögren \\ Sendromu Birlikteliği
}

Özlem Erçen Diken', Aydın Çiledağ ${ }^{2}$, Çetin Atasoy³ ${ }^{3}$ Özlem Özdemir Kumbasar ${ }^{2}$

\section{Abstract}

Sarcoidosis and Siögren's syndrome are chronic multi-systemic diseases. The association of these two diseases was reported only in 1\% of patients with Siögren's syndrome. We present this rare case in order to draw the attention to the prognostic importance of this difference. A 62-year-old female patient presented to our hospital with the complaints of dyspnea and a dry cough. Dry eye and dry mouth were present. Laboratory analyses revealed serum anti SS-A (Ro) $(+++)$ antibody positivity. Chest computerized tomography revealed lymphadenopathy and reticular-micronodular appearance evident. Transbronchial needle aspiration guided with endobronchial ultrasound was conducted through $10 R$ and 7 lymph nodes. Pathology was compatible with sarcoidosis. Pulmonary function test revealed $40 \%$ carbon monoxide diffusion capacity. It is of prognostic importance to distinguish sarcoidosis imitating Siögren's syndrome from the association of sarcoidosis- Siögren's syndrome, since sarcoidosis mostly limits itself and recover by itself without any functional restrictions, but the pulmonary involvement of Siögren's syndrome causes permanent defects.

Key words: Sarcoidosis, sarcoidosis- Siögren syndrome association, Siögren's syndrome.

\section{Özet}

Sarkoidoz ve Siögren sendromu kronik multisistemik hastalıklardır. Bu iki hastalığın birlikteliği sadece Sjögren sendromlu hastaların \% 1'inde bildirilmiştir. Sarkoidoz ve Siögren sendromu birlikteliği olan bu olguyu nadir görülmesi ve bu ayrımın prognostik öneme sahip olduğuna dikkat çekmek için bildiriyoruz. Altmış iki yaşında kadın hasta, nefes darlığı ve kuru öksürük şikâyeti ile hastanemize başvurdu. Göz ve ağızda kuruma mevcuttu. Laboratuvar incelemesinde serum anti SS-A (Ro) $(+++)$ antikoru pozitifliği gösterildi. Toraks bilgisayarlı tomografisinde lenfadenopati ve retiküler- mikronodüler görünüm saptandı. Lenf bezlerinden 10R ve 7 nolu istasyondan endobronşiyal ultrason eşliğinde transbronşiyal iğne aspirasyonu yapıldı. Patoloji sarkoidoz ile uyumlu bulundu. Karbonmonoksit difüzyon kapasitesi \%40 olarak saptandı. Siögren sendromunu taklit eden sarkoidozu, sarkoidoz- sjögren sendromu birlikteliğinden ayırt etmek prognostik öneme sahiptir, çünkü sarkoidoz çoğunlukla kendini sınırlayıp, fonksiyonel kısılama olmaksızın kendiliğinden iyileşebilirken, Sjögren sendromunun pulmoner tutulumu kalıcı defektlere yol açmaktadır.

Anahtar Sözcükler: Sarkoidoz, sarkoidoz-sjögren sendromu ilişkisi, Siögren sendromu.
'Department of Chest Diseases, Hitit University, Faculty of Medicine, Çorum, Turkey

${ }^{2}$ Department of Chest Diseases, Ankara University, Faculty of

Medicine, Ankara, Turkey

${ }^{3}$ Department of Radiology, Ankara University, Faculty of Medicine, Ankara, Turkey Submitted (Başvuru tarihi): 29.05.2015 Accepted (Kabul tarihi): 14.08.2015

Correspondence (iletişim): Özlem Erçen Diken, Department of Chest Diseases, Hitit University, Faculty of Medicine, Çorum, Turkey

e-mail: oercen@hotmail.com
'Hitit Üniversitesi Tıp Fakültesi, Göğüs Hastalıkları Anabilim Dalı, Çorum

${ }^{2}$ Ankara Üniversitesi Tıp Fakültesi, Göğüs Hastalıkları Anabilim Dalı, Ankara

${ }^{3}$ Ankara Üniversitesi Tıp Fakültesi, Radyoloji Anabilim Dalı, Ankara 
Sarcoidosis and Siögren's syndrome (SS) are both chronic multisystem diseases and have an autoimmune character. SS primarily involves the primer exocrine glands. Among the characteristics are: dry eyes, dry mouth, fever, fatigue, and muscle and joint pains. Anti-Ro and anti-La autoantibodies are characteristic of SS. Sarcoidosis mostly involves pulmonary parenchyma (1). Although its primary characteristic feature is hilar lymphadenopathy and pulmonary granulomas, sarcoidosis is a multisystemic disease and its early symptoms are mostly obscure, which makes it difficult to diagnose (2). Recent studies have suggested that scleroderma, mixed connective tissue disease, dermatomyositis or polymyositis may accompany sarcoidosis (3). Sarcoidosis shares a few characteristics with SS that might be insidious and surface years later. Sarcoidosis is also an exclusion criterion to make a SS diagnosis. However, even though actual sarcoidosis and SS association is reported in literature, it accounts for only $1 \%$ among all SS patients (4). We present our case with the association of sarcoidosis and SS to draw attention to the facts that it is a rare case and this difference is of prognostic importance.

\section{CASE}

A 62-year-old female patient presented to our hospital with complaints of difficulty in breathing, dry cough, and fatigue that began seven months earlier. She was nonsmoker and there was no history of occupational or environmental exposure. The patient was not taking any regular medication.

Her physical examination revealed bilateral fine crepitations and erythema lesions had commenced a day previously on the left arm (Figure 1). Other system examinations were normal. Arterial blood gases measurement revealed $\mathrm{PaO}_{2}$ value as $74 \mathrm{mmHg}$. Laboratory analyses showed serum anti SS-A (Ro) 52kD (immunoblot) $(+++)$ antibody positivity and SS-A (Ro) 60kD (immunoblot) $(+++)$ antibody positivity. Other auto-antibodies were normal. Such high values, as $\mathrm{C}$-reactive protein (CRP) $15.5 \mathrm{mg} / \mathrm{L}(0-3)$ and erythrocyte sedimentation rate (ESR) $60 \mathrm{~mm} /$ hour $(0-25)$ were established in hematologic and biochemical analyses. Other laboratory tests, including angiotensin converting enzyme (ACE) levels, serum calcium values and 24 -hour urine calcium values were within normal limits. Chest radiography revealed bilateral hilar fullness and nodular infiltration increase (Figure 2). $\mathrm{ECHO}$ findings were normal. Chest computerized tomography established mediastinal, paracardiac and bilateral hilar-involved lymphadenopathy (Figure 3), bilateral re- ticular-micronodular appearance, evident in the lower lobes and subpleural areas, irregular thickening in fissure structures, and subpleural nodules, with the largest having a diameter of $1.5 \mathrm{~cm}$ in the upper lobes and lingula in both lungs (Figure 4). Radiologic consultation revealed that the present findings could be related with SS; however, mediastinal lymph nodes suggested they should be studied more in detail. Endobronchial ultrasound-guided transbronchial needle aspiration (EBUS-TBNA) was conducted through 10R and 7 stations. Histopathologic evalvation of the lymph nodes and the lesion on the left arm revealed non-necrotizing granulomatous inflammation. The patient was diagnosed with sarcoidosis due to appropriate clinical, radiological and histopathological findings. The patient was established to have dry eyes bilaterally with the Schirmer's test, relevant to SS. The patient was diagnosed with SS and a further biopsy was not performed. Dry mouth was also present. A pulmonary function test established a decreased carbon monoxide diffusion capacity (40\%). The low carbon monoxide diffusion capacity level was compatible with SS findings. Spirometry was normal. The patient was accepted to have sarcoidosis-SS association. Then, we decided to undertake the patient's treatment as SS, which had poorer prognosis than sarcoidosis. Oral prednisone was commenced at a dose of $30 \mathrm{mg} /$ day and hydroxychloroquin therapy was added. Skin lesions including buttock sclerosis, ILD, and hilar lymphadenopathy also responded to the treatment. Prednisone was tapered gradually to 17.5 $\mathrm{mg} /$ day with no relapse during a follow-up period of nine months.

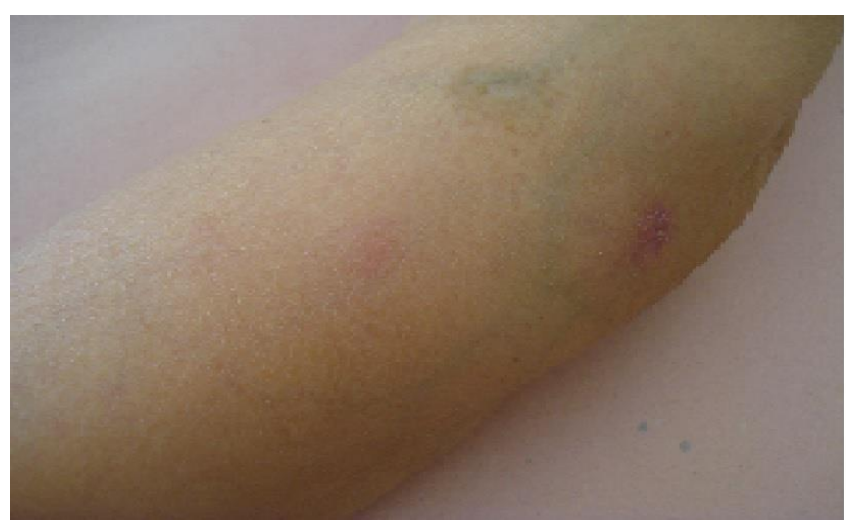

Figure 1: Arm lesion

\section{DISCUSSION}

The revised American-European criteria were defined for primary SS (PSS) diagnosis. These criteria are dry eye symptoms, dry mouth symptoms, demonstration of dry eyes with such tests as Schirmer's, auto-antibody positivity 
such as anti-Ro and anti-La, their histologic demonstration, and evidencing with such imaging techniques as scintigraphy (STC) (or showing the salivary gland involvement with saliva testing). These criteria are not used in clinical practice and each patient does not meet the entire criteria. However, they are noted as useful to exclude diseases that might be confused with SS. The presence of four or more of the criteria would probably call for a SS diagnosis (97\% sensitive, 90 specific). Criteria noted in the revised American-European criteria as, serum anti SS-A (Ro) antibody positivity, dry eye symptoms, dry mouth symptoms, and dry eye demonstrated with Schirmer's test, are necessary for diagnosis, were met in our case. Differential diagnosis also includes some exclusion criteria, such as head and neck irradiation, $\mathrm{HCV}$ virus infection, AIDS, lymphoma, sarcoidosis, graftversus-host disease (GVHD), and recent anticholinergic drug use. Although, in differential diagnosis there is possibility of all immune diseases, scleroderma-SS association and systemic lupus erythematosus (SLE)-SS association are also present in the revised American-European criteria. In a recent study, the authors reported concomitant sarcoidosis and connective tissue disease, which include scleroderma, mixed connective tissue disease, dermatomyositis or polymyositis, rheumatoid arthritis and psoriatic arthritis (3). Sarcoidosis-SS association is present in the exclusion criteria as well, even though it is not reported. In the literature, this association was reported to be $1 \%(4)$. In our case, sarcoidosis diagnosis was made using endobronchial ultrasound-guided transbronchial needle aspiration (EBUS-TBNA) from 10R and 7 stations and lesion biopsy from the left arm. Thus, the sarcoidosisSS association diagnosis was made.

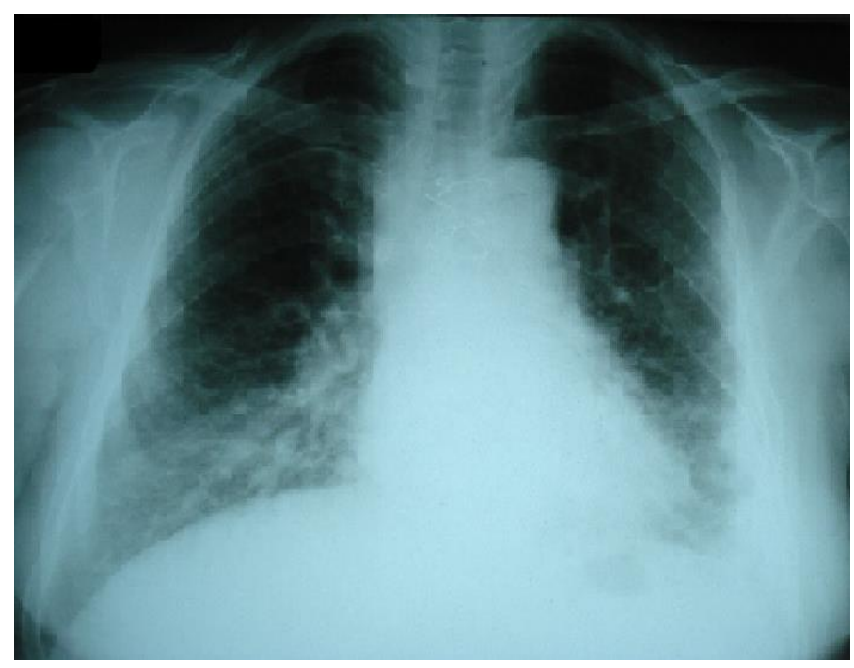

Figure 2: Chest radiography

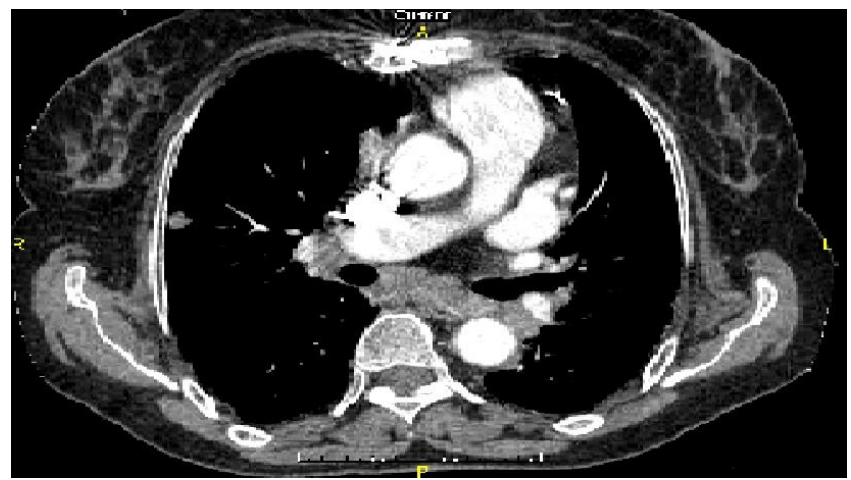

Figure 3: Chest computerized tomography

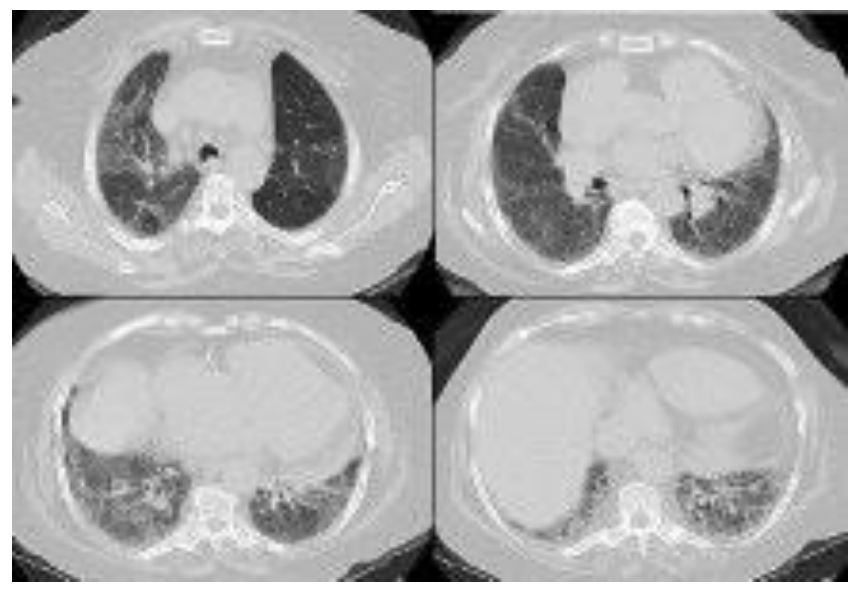

Figure 4: Chest computerized tomography (parenchyma)

When checked the literature there were only a few articles that draw attention to this association and that also underline that sarcoidosis should not be used as an exclusion criterion for SS diagnosis. Hirokazu et al. (4) reported noncaseified granulomas in video-assisted thoracic surgery (VATS), conducted for multiple pulmonary nodules, in a patient diagnosed with SS. Fuke et al. (5) pathologically diagnosed sarcoidosis in 28 patients together with SS. Hansen et al. (1) who pathologically showed sarcoid granulomas in legs, arms, and cheeks. In their case, they diagnosed SS by using the revised American-European criteria. They reported that they demonstrated sarcoidosis and Siögren's association but noted sarcoidosis should not be present as an exclusion criterion in diagnosing SS. Mansour et al. (2) and defined their accounting for the diagnosis criteria of both diseases as an association in their series of five cases and they made the SS diagnosis by using American-European criteria (at least one auto-antibody or accounting for four criteria out of six accompanying biopsy). They also pathologically demonstrated sarcoidosis diagnosis.

A pathologic diagnosis of SS is not much used in practice (in 1998, lymphocytic interstitial pneumonia through lung biopsy following the pathologic diagnosis of sarcoidosis, 
was shown to be complying with SS and received the diagnosis of sarcoidosis-SS association) (6). In the literature, there are only a few cases pathologically diagnosed with SS. We too did not make the SS diagnosis pathologically. In sarcoidosis diagnosis, pathologic diagnosis is important and the diagnosis was made pathologically in our case both through lesions in arm and lesions in lungs. Skin lesions such as erythema nodosum are also present in sarcoidosis and they are characterized with granuloma. As in our case, such areas may also be used for diagnostic purposes (7).

Sarcoidosis may limit itself and recover without any functional effects. However, in SS, pulmonary involvement may cause permanent damage. Therefore, diagnoses of sarcoidosis-SS association or sarcoidosis imitating SS, have prognostic importance. In 2004, 28 out of a 59 . case meta-analysis were reported to have sarcoidosis and SS association and the remaining 25 had sarcoidosis imitating SS (8). American-European criteria was reported to be $93 \%$ sensitive and $92 \%$ specific, and when suspected from an association, these criteria were noted to be used in the diagnosis of SS and that sarcoidosis needs to be excluded from the exclusion criteria of SS. In 2000, 464 cases with SS were analyzed, and five cases were shown to have sarcoidosis-SS association, and three cases were demonstrated to have sarcoidosis that imitates SS (9). Although no cases present in Turkey have been reported, it is a confusion that may be observed in clinical practice despite its rarity.

Consequently, sarcoidosis that imitates SS or sarcoidosisSS association is conditions that are required to be distinguished and such a distinction is important due to the fact that the prognosis of SS is comparably poorer. The presence of sarcoidosis in the exclusion criteria for diagnosing SS can cause diagnostic confusion. Just as in our case, a diagnosis of sarcoidosis does not eliminate the diagnosis of SS. Sarcoidosis may imitate SS by bearing some characteristics of SS but the association of sarcoidosis and SS should also be borne in mind.

\section{CONFLICTS OF INTEREST}

None declared.

\section{AUTHOR CONTRIBUTIONS}

Concept - Ö.E.D., A.Ç., Ç.A., Ö.Ö.K.; Planning and Design - Ö.E.D., A.Ç., Ç.A., Ö.Ö.K.; Supervision Ö.E.D., A.Ç., Ç.A., Ö.Ö.K.; Funding -; Materials -; Data
Collection and/or Processing - Ö.E.D.; Analysis and/or Interpretation - A.Ç.; Literature Review - Ö.Ö.K.; Writing - Ö.E.D.; Critical Review - Ö.Ö.K.

\section{YAZAR KATKILARI}

Fikir - Ö.E.D., A.Ç., Ç.A., Ö.Ö.K.; Tasarım ve Dizayn Ö.E.D., A.Ç., Ç.A., Ö.Ö.K.; Denetleme - Ö.E.D., A.Ç., Ç.A., Ö.Ö.K.; Kaynaklar -; Malzemeler -; Veri Toplama ve/veya İşleme - Ö.E.D.; Analiz ve/veya Yorum - A.Ç.; Literatür Taraması - Ö.Ö.K.; Yazıyı Yazan - Ö.E.D.; Eleştirel İnceleme - Ö.Ö.K.

\section{REFERENCES}

1. Hansen SR, Hetta AK, Omdal R. Primary Sjögren's syndrome and sarcoidosis: coexistence more than by chance? Scand J Rheumatol 2008; 37:485-6. [CrossRef]

2. Mansour MJ, Al-Hashimi I, Wright JM. Coexistence of Siögren's syndrome and sarcoidosis: a report of five cases. J Oral Pathol Med 2007; 36:337-41. [CrossRef]

3. Judson MA, Shapiro L, Freitas S, Polychronopoulos VS, Highland KB. Concomitant sarcoidosis and a connective tissue disease: review of the clinical findings and postulations concerning their association. Respir Med 2013; 107:1453-9. [CrossRef]

4. Tokuyasu $H$, Harada $T$, Touge $H$, Kawasaki $Y$, Maeda R, Isowa $N$, et al. Primary Sjögren's syndrome complicated by sarcoidosis. Intern Med 2008; 47:2049-52. [CrossRef

5. Fuke S, Yamaguchi E, Makita H, Morikawa T, Nishimura M. A case of sarcoidosis complicated by primary Siögren's syndrome. Nihon Kokyuki Gakkai Zasshi 2002; 40:686-91

6. Lois M, Roman J, Holland W, Agudelo C. Coexisting Siögren's syndrome and sarcoidosis in the lung. Semin Arthritis Rheum 1998; 28:31-40. [CrossRef]

7. Takenoshita H, Yamamoto T. Erythema nodosum-like cutaneous lesions of sarcoidosis showing livedoid changes in a patient with sarcoidosis and Siögren's syndrome. Eur J Dermatol 2010; 20:640-1. [CrossRef]

8. Ramos-Casals M, Brito-Zerón P, García-Carrasco M, Font J. Sarcoidosis or Siögren syndrome? Clues to defining mimicry or coexistence in 59 cases. Medicine (Baltimore) $2004 ; 83: 85-95$.

9. Gal I, Kovacs J, Zeher M. Case series: coexistence of Siögren's syndrome and sarcoidosis. J Rheumatol 2000; 27:2507-10. 